\title{
Abnormal Branching Pattern of the Axillary Artery and its Clinical Significance
}

\author{
Patrón de Ramificación Anormal de la Arteria Axilar y su Significado Clínico \\ "T. Ramesh Rao; **Prakashchandra Shetty \& ${ }^{* * *}$ R. Suresh
}

RAMESH RAO, T.; SHETTY, P. \& SURESH, R. Abnormal branching pattern of the axillary artery and its clinical significance. Int. J. Morphol.,26(2):389-392, 2008.

SUMMARY: The increasing use of invasive diagnostic and interventional procedures in cardiovascular diseases makes it important that the type and frequency of vascular variations are well documented and understood. Sound knowledge of neurovascular variations is important for surgeons who remove axillary lymph nodes, to anesthesiologists, and orthopedic surgeons, considering the frequency of procedures done in this region. An unusual variation in the branching pattern of axillary artery was observed on the left side of a 60 year old female cadaver. In the present case the course and distribution of the first and second part of the axillary artery were normal. But a rare case of unusual origin of subscapular, anterior and posterior circumflex humeral, profunda brachii artery and ulnar collateral arteries from a common trunk were found on the left side during routine dissection. This common trunk was found arising from the third part of the axillary artery and at its commencement it was found passing between the two roots of the median nerve. Cases with this kind of variations should be examined or operated carefully during surgical or electrophysiological procedures.

KEY WORDS: Axillary artery; Subclavian artery; Brachial artery; Vascular variation.

\section{INTRODUCTION}

Axillary artery is the direct continuation of the subclavian artery from the outer border of the first rib. The course of the axillary artery is anatomically divided into three parts by the pectoralis minor muscle. The first part begins at the lateral border of the first rib and extends to the medial border of the pectoralis minor muscle. The first part is enclosed within the axillary sheath along with the axillary vein and brachial plexus. The second part of the axillary artery lies deep to the pectoralis minor muscle. The third part lies between the lateral border of the pectoralis minor muscle and the inferior border of the teres major muscle.

The axillary artery is usually described as giving off six branches. The first part of the artery gives superior thoracic artery. The second part of the artery gives lateral thoracic and thoracoacromial branches. The third part of the artery gives subscapular artery, anterior circumflex humeral and posterior circumflex humeral arteries. There is an extensive collateral circulation associated with the branches of subclavian and axillary arteries, particularly around the scapula. This clearly becomes of clinical significance during injury of the axillary artery.

\section{CASE REPORT}

During routine dissection for medical undergraduates, in a 60 year old female cadaver we observed unilateral variations in the branching pattern of the third part of the left axillary artery. However, the course and distribution of the first and second part of the axillary artery were normal. From the third part of the axillary artery a rare case of unusual origin of subscapular, anterior and posterior circumflex humeral, profunda brachii artery and ulnar collateral arteries from a common trunk were found on the left side during routine dissection. This common trunk was arising from the third part of the axillary artery and at its commencement it was found passing between the two roots of the median nerve. After running downwards and medially for about $2 \mathrm{~cm}$ the common trunk gave the subscapular branch from its medial aspect and anterior and posterior circumflex humeral branches from its posterolateral aspect (Fig. 1). In its further course the common trunk at the commencement of the radial groove gave the profunda brachii branch and it continued further down along with the ulnar nerve to end by giving superior and inferior ulnar collateral branches in the arm (Fig. 2).

\footnotetext{
* Department of Para clinical Sciences, Faculty of Medical Sciences, The University of the West Indies, St. Augustine, Trinidad.

** Department of Anatomy, Kasturba Medical College, Manipal University, Manipal, Udupi District - 576104, Karnataka State, India.

${ }^{* * *}$ Department of Pre-clinical Sciences, Faculty of Medical Sciences, The University of the West Indies, St. Augustine, Trinidad.
} 


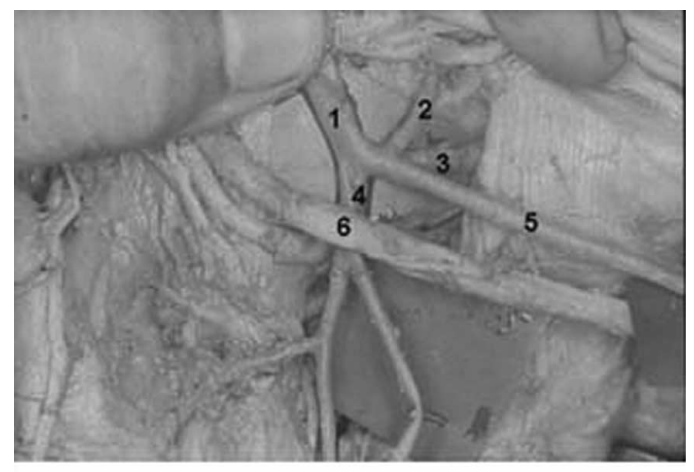

Fig. 1. 1. Common trunk; 2. Anterior circunflex humeral artery; 3. Posterior circunflex humeral artery; 4. Subscapular artery; 5. Continuation of common trunk; 6. Radial nerve.

\section{DISCUSSION}

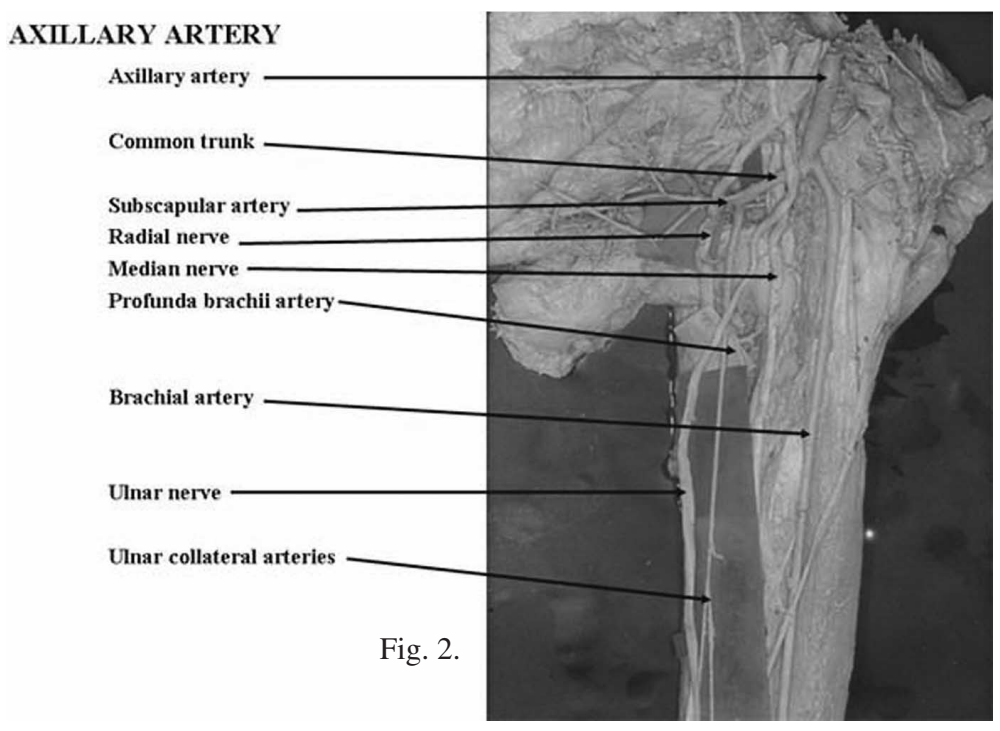

Earlier studies by many observers showed that variations in the branching pattern of the axillary artery are very common. The axillary artery bifurcated into almost equal size trunks. The superficial among the two continued as the brachial artery. The abnormal deep trunk bifurcated into a common circumflex humeral-subscapular trunk and a profunda brachii artery. The common circumflex humeralsubscapular trunk further divided to give anterior and posterior circumflex humeral arteries and subscapular artery (George et al., 2007).

Magden et al. (2007) observed "abnormal" branching pattern of the axillary artery and unusual branch to the serratus anterior muscle, which originated directly from the first part of the axillary artery as the first branch. The lateral thoracic and thoracodorsal arteries arose together from the third part of the axillary artery as "a lateral thoracicthoracodorsal" common trunk. The superior thoracic artery was out of the position. The circumflex scapular artery originated directly from the third part of the axillary artery. The subscapular artery was not present.

Anatomic variations in the major arteries of the upper limb have been reported. These include absence of the radial artery and the presence of a superficial brachial artery as well as a superficial ulnar artery. Branches of the upper limb arteries have been used for coronary bypass and flaps in reconstructive surgery. Accurate knowledge of the normal and variant arterial pattern of the human upper extremities is important both for reparative surgery and for angiography (Yoshinaga et al., 2006).

The axillary artery is usually described as giving off six branches, although the number varies because two or more arteries often arise together instead of separately, or two branches of an artery arise separately instead of from the usual common trunk. Thus, instead of six, there may be anywhere from 5 to 11 branches. A rare but striking anomaly of the axillary artery is for it to divide into two branches that proceed down the arm. When this occurs, usually one of the arterial stems in the arm runs more superficially than does the other, and they are, therefore sometimes distinguished as brachial artery and superficial brachial artery. This apparent doubling of the brachial artery more commonly occurs in the arm than in the axilla (Hollinshead \& Rosse, 1985).

In up to $30 \%$ of cases, the subscapular artery can arise from a common trunk with the posterior circumflex humeral artery. Occasionally the subscapular, circumflex humeral and profunda brachii arteries arise in common, in which case, branches of the brachial plexus surround this common vessel instead of axillary artery. The posterior circumflex humeral artery may arise from the profunda brachii artery and pass back below the teres major instead of passing through the quadrangular space (Johnson \& Ellis, 2005).

During the exposure of an anomalous muscle, the third part of the axillary artery was found beneath the latissimocondyloideus muscle and was having anomalous branching pattern. The third part of the axillary artery gave only one main trunk, which divided into two main branches, lateral and medial. The lateral branch gave (I) common humeral circumflex artery, which divided into anterior and posterior circumflex humeral arteries, the latter continued as the profunda brachii artery. (II) Superior ulnar collateral artery that ran along the medial side of the arm up to elbow 
joint. The medial branch was the subscapular artery, which in turn gave three circumflex scapular arteries; one medial and two lateral branches to the scapular border, the artery then continued as thoraco-dorsal artery, with the thoracodorsal nerve and supplied the medial wall of axilla and latissimus dorsi muscle (Soubhagya et al., 2006).

Kogan \& Lewinson (1998) for the first time observed a branch arising from the axillary artery, passing as a common trunk between the roots of the median nerve, and dividing into two branches. The lateral one gave rise to muscular branches supplying the shoulder and fasciae, while the medial one descended on the anterior aspect of the axillary fossa, reaching the hypogastric region, and anastomose with the superficial epigastric artery, which is a branch of the femoral artery. They named this rare variant medial branch as the thoracoepigastric artery.

Jurjus et al. (1999) showed the presence of an unusual bilateral variation in the arterial pattern of the axilla. Each axilla contained two axillary arteries of similar origins but different patterns of branching and fate. The first part of each axillary artery was a single vessel as is the norm. It gave off a supreme thoracic artery and then bifurcated into two medium-sized arteries hence referred to as regular and variant. The variant artery ran in an antero-medial course, partly covered by the one axillary vein. The regular artery gave off the thoracoacromial and two posterior branches from its second part, the anterior and posterior humeral circumflex arteries from its third part, and then continued as the brachial artery with all the usual branches except the profunda brachii on the right side. The variant gave off five arteries from the second part, a thoracoacromial artery, two separate long thoracic arteries each with a branch that ran along the intercostobrachial nerve to the arm, and two posterior branches. In the third part of the variant, the subscapular artery arose with its usual branches plus a common origin for two additional humeral circumflex arteries. The variant terminated as the profunda brachii artery to the right side while on the left side it terminated in muscular branches to the triceps. Hence, the arterial blood supply to the upper limb, and the axillary region in particular, was shared on both sides by two major arteries instead of one. These two arteries emanated from the first part of the axillary artery and may represent persisting branches of the capillary plexus of the developing limb buds.

The branches of the third part of the axillary artery are subject to great variation. The two circumflex arteries may arise from a common trunk, usually alone or rarely together with the profunda brachii and muscular branches. Very rarely it may give rise to a common trunk, from which may arise the subscapular, anterior and posterior circumflex humeral, profunda brachii, and ulnar collateral arteries (Bergman et al., 1988).

Sound knowledge of axillary artery variation is important for surgeons, since except for the popliteal, the axillary artery is more frequently lacerated by violence than any other artery, being more susceptible when diseased. It has been ruptured in attempt to reduce old dislocations, especially when the artery is adherent to the articular capsule (Williams et al., 1995).

Detection of developmental variations of the axillary artery and evaluation of its stenotic areas is very important for surgical interventions, and involves specific diagnostic imaging techniques for vascular lesions including contrast arteriography, duplex ultrasonography and MRI. Examinations of obtained images in cases of unusual and complicated variations of vascular pattern of the axillary may lead to confusion in interpretation of data. Awareness about details and topographic anatomy of variations of the axillary artery may serve as a useful guide for both radiologists and vascular surgeons. It may help to prevent diagnostic errors, influence surgical tactics and interventional procedures and avoid complications during the surgery of the axilla region.

RAMESH RAO, T.; SHETTY, P. \& SURESH, R. Patrón de ramificación anormal de la arteria axilar y su significado clínico. Int. J. Morphol., 26(2):389-392, 2008.

RESUMEN: El incremento del uso de diagnósticos invasivos y procedimientos de intervención en las enfermedades cardiovasculares hace que sea importante que el tipo y la frecuencia de las variaciones vasculares estén bien documentados y entendidos. Un buen conocimiento de las variaciones neurovasculares es importante para los cirujanos que extirpan linfonodos axilares, para anestesiólogos y cirujanos ortopédicos, considerando la frecuencia de los procedimientos realizados en esta región. Una inusual variación en el patrón de ramificación de la arteria axilar se observó en el lado izquierdo de un cadáver de sexo femenino de 60 años de edad. En el presente caso, el curso y la distribución de la primera y segunda parte de la arteria axilar fueron normales. Sin embargo, fue encontrado en el lado izquierdo, durante la disección de rutina, un caso raro, de origen inusual, de las arterias subescapular cirunflejas humerales anterior y posterior, braquial profunda y arterias colaterales ulnares desde un tronco común. Este tronco común se encontró derivado de la tercera parte de la arteria axilar y en su comienzo se comprobó que pasaba entre las dos raíces del nervio mediano. Los casos con este tipo de variaciones deben ser examinados u operados cuidadosamente durante prodecimientos quirúrgicos o electrofisiológicos.

PALABRAS CLAVE: Arteria axilar; Arteria subclavia, Arteria braquial; Variación vascular. 


\section{REFERENCES}

Bergman, R. A.; Thomson, S. A.; Afifi, A. K. \& Saadeh, F. A. Compendium of Anatomic Variation. In: Cardiovascular system. Baltimore, Urban and Schwarzenber, 1988. pp. 72-3.

George, B. M.; Nayak, S. \& Kumar, P. Clinically significant neurovascular variations in the axilla and the arm - a case report. Neuroanatomy, 6(1):36-8, 2007.

Hollinshead, W. H. \& Rosse, C. Text Book of Anatomy. $4^{\text {th }}$ Ed. Harper \& Row, Philadelphia, 1985. pp.187-9.

Johnson, D. \& Ellis, H. Pectoral girdle and upper limb. In: Standring, S. Ed. Gray's Anatomy. 39 $9^{\text {th }}$ ed. Edinburgh, Elsevier, 2005. p. 845.

Jurjus, A. R.; Correa-De-Aruaujo, R. \& Bohn, R. C. Bilateral double axillary artery: embryological basis and clinical implications. Clin. Anat., 12(2):135-40, 1999.

Kogan, I. \& Lewinson, D. Variation in the branching of the axillary artery. A description of a rare case. Acta Anat. (Basel), 162(4):238-40, 1998.

Magden, O.; Gocmen-Mas, N. \& Caglar, B. Multiple variations in the axillary arterial tree relevant to plastic surgery: A case report. Int. J. Morphol., 25(2):357-61, 2007.

Soubhagya, R. N.; Latha, V. P.; Ashwin, K.; Madhan, K. S. J. \& Ganesh, C. K. Coexistence of an axillary arch muscle (Latissimocondyloideus muscle) with an unusual axillary artery branching: Case report and review. Int. J. Morphol., 24(2):147-50, 2006.

Williams, P. L.; Bennister, L. H.; Berry, M. M.; Collins, P.; Dyson, M.; Dussek, J. E. \& Ferguson, M. W. J. Gray's Anatomy. In: Cardiovascular system. Gabella, G. Ed. 38th Ed. Edinburg, Churchill Livingestone, 1995. pp.1537-8.

Yoshinaga, K.; Kodama, K.; Kameta, K.; Karasawa, N.; Kanenaka, N.; Kohno, S. \& Suganuma, T. A rare variation in the branching pattern of the axillary artery. Indian J. Plast. Surg., 39:222-3, 2006.
Correpondence to:

Dr. T. Ramesh Rao

Department of Para clinical Sciences

Faculty of Medical Sciences

The University of the West Indies

St. Augustine

TRINIDAD

Tel. - 001-868-662-1472, Extn. 5005

Fax: - 001-868-662-1472

Email: varun1195@yahoo.com

Received: 05-10-2007

Accepted: 18-01-2008 